\title{
Öffentliche Institutionen: Wandel durch Steuerung?
}

Die Größe eines Wortes stellt die relative Häufigkeit in allen Beiträgen dar.

\section{Doppik Wirtschaftlichkeit}

Aufgaben

\section{Iransparenz}

Ressourcen strategische Privatwirtschaft

\section{Umsetzung Organisation.} Entwicklung Behörde

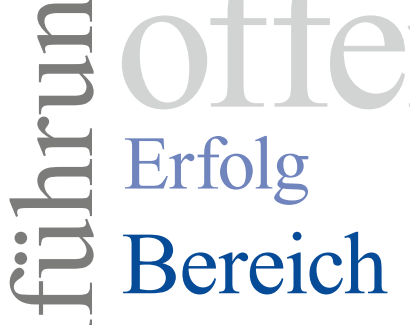

일
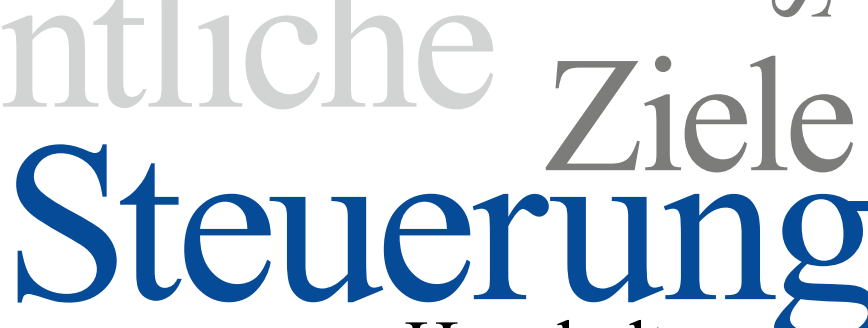

Maßnahmen 